\title{
Research Paper: Opioid Receptors Gene Polymorphism and Heroin Dependence in Iran
}

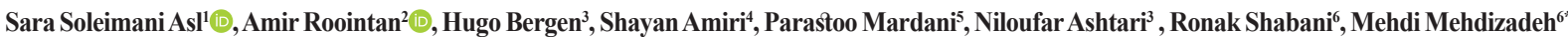

1. Neurophysiology Research Center, Hamadan University of Medical Sciences, Hamadan, Iran.

2. Department of Medical Biotechnology, School of Advanced Medical Sciences and Technologies, Shiraz University of Medical Sciences, Shiraz, Iran

3. Department of Human Anatomy and Cell Sciences, Rady Faculty of Health Sciences, University of Manitoba, Winnipeg, Manitoba, Canada.

4. Department of Pharmacology, School of Medicine, Tehran University of Medical Sciences, Tehran, Iran.

5. Department of Biology, Faculty of Science, Tehran Branch, Payame Noor University, Tehran, Iran.

6. Cellular and Molecular Research Center, Department of Anatomy, Faculty of Advanced Technologies in Medicine, Iran University of Medical Sciences, Tehran, Iran.

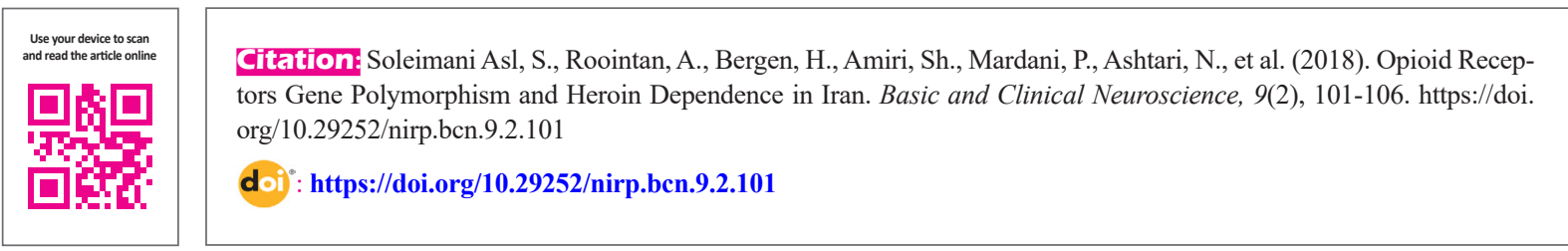

Article info:

Received: 09 September 2017

First Revision: 03 October 2017

Accepted: 10 November 2017
Key Words:

$\mu$-opioid receptor, $\kappa$-opioid receptor, $\delta$-opioid receptor, Single nucleotide polymorphism, Heroin

\begin{abstract}
A B S T R A C T
Introduction: Genes often have multiple polymorphisms that interact with each other and the environment in different individuals. Variability in the opioid receptors can influence opiate withdrawal and dependence. In humans, A118G Single Nucleotide Polymorphisms (SNP) on $\mu$-Opioid Receptor (MOR), $36 \mathrm{G}>\mathrm{T}$ in $\kappa$-Opioid Receptor (KOR), and T921C in the $\delta$-Opioid Receptor (DOR) have been found to associate with substance dependence.
\end{abstract}

Methods: To investigate the association between opioid receptors gene polymorphism and heroin addiction, 100 control subjects with no history of opioid use, and 100 heroin addicts $(50 \%$ males and 50\% females) in Tehran (capital of Iran), were evaluated. A118G, $36 \mathrm{G}>\mathrm{T}$, and T921C SNPs on the MOR, KOR, DOR genes, respectively, were genotyped by sequencing.

Results: We found no differences in either allele or genotype frequency for MOR, KOR and DOR genes SNPs between controls and subjects addicted to heroin.

Conclusion: The relationships among polymorphisms may be important in determining the risk profile for complex diseases such as addiction, but opioid addiction is a multifactorial syndrome which is partially hereditary and partially affected by the environment.

\section{Introduction}

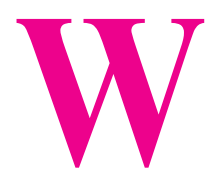

hile severe social and economic problems will result from using illegal drugs in the society, pathogenesis of addictive disorders and mechanisms of therapeutic strate- gies for drug addicts have not been well understood yet (Mayer et al., 1997). Transition from an occasional user to an addict depends on the drug user, drug, and environment (Yuferov, Levran, Proudnikov, Nielsen, \& Kreek, 2010). The $\mu$-Opioid Receptor (MOR), $\kappa$-Opioid Receptor (KOR) and $\delta$-Opioid Receptor (DOR) mediate the impact of opioids including toler-

* Corresponding Author:

Mehdi Mehdizadeh, PhD

Address: Cellular and Molecular Research Center, Department of Anatomy, Faculty of Advanced Technologies in Medicine, Iran University of Medical Sciences, Tehran, Iran.

Tel:+98 (21) 88622689

E-mail:mehdizadeh.m@iums.ac.ir 
ance, analgesia, dependence, and reward (Stein, 2016). Several lines of evidence indicate that genetic variations in the MOR gene (OPRM1), KOR gene (OPRK1) and DOR gene (OPRD1) can influence the expression, structure, or function of the receptors and ultimately result in increased or decreased susceptibility to opioid dependency (Crist, Doyle, Kampman, \& Berrettini, 2016; Sharafshah et al., 2017).

Single nucleotide polymorphisms (SNPs) in OPRM1, OPRK1, and OPRD1 are candidates for their role in mediating differences in the opioid addiction. Genetic variation in these genes may create or function (which might result in receptors with altered expression) structured decrease or increase vulnerability to reliance on substance (Bond et al., 1998; Koch et al., 2000; Wang, Quillan, Winans, Lucas, \& Sadée, 2001), and impact treatment response to opioid antagonists (Oslin et al., 2003). A number of studies have reported that $\mathrm{A} 118 \mathrm{G}$, in the first exon of the OPRM1 gene can be influential in individual susceptibility toward opioid dependency (Kreek, Bart, Lilly, Laforge, \& Nielsen, 2005). Also, 36 G $>$ T SNP at exon 1 of the KOR gene has been reported to contribute in predisposition to voluntary alcohol-drinking behavior in experimental animals (Saito et al., 2003).

In humans, this SNP has been found to be substantially associated with a population of heroin addicts of West European, Caucasian origin (Gerra et al., 2007). It has been reported that T921C SNP on the 3 exon OPRD1 is associated with increased substance abuse (Gelernter \& Kranzler, 2000; Mayer et al., 1997). In addition, dependence on opioids is a medical and social problem in the world as well as Iran (Degenhardt et al., 2013; Majdzadeh et al., 2009; Shadnia, Soltaninejad, Heydari, Sasanian, \& Abdollahi, 2008). Thus, further research is needed to recognize genetic variables that contribute to the progress of opioid addiction, to confirm probable genetic associations and to increase the neurobiological understanding of opioid dependence in order to find more potent analgesics with minimal unwanted actions. The principle objective of this research was to recognize genetic polymorphisms associated with the exclusive vulnerability toward opioid addiction and reproduce previous research in this field. Identifying these genetic markers will help detect people at risk for opiate addiction and provide better treatment options for them.

\section{Methods}

\subsection{Study subjects}

One hundred control subjects with no history of opioid use and one hundred heroin addicts (50\% males and 50\% females, aged 20-45 years) volunteered for the study in Tehran, Iran. The control group was recruited from university students and employees while the study group was recruited from drug rehabilitation centers in Tehran. Both groups participated in the research with their written consent. The participants were not paid and agreed to participate in the study voluntarily. In drug dependent individuals, heroin abuse was confirmed by psychiatric examination. Exclusion criteria included polydrug abusers, utilization of other narcotics, excessive alcohol intake, and psychotropic factors.

\subsection{DNA extraction and PCR amplification}

Twenty milliliters of EDTA-treated blood was obtained from peripheral vein of subjects and control groups. We used a DNA kit (Cinnagen, Tehran, Iran) for DNA extraction according to the manufacturer's protocols. Briefly, lysis buffer was added to the sample and vortexed. Then, the precipitation solution was added to the sample and the solution transferred to a collection tube and centrifuged at $13000 \mathrm{rpm}$. The spin column was washed and the DNA was eluted to a tube by elution buffer.

\subsection{Selection and genotyping of SNPs}

The SNPs A118G in exon 1 of the OPRM1 (Grösch, Niederberger, Lötsch, Skarke, \& Geisslinger, 2001), 36 $\mathrm{G}>\mathrm{T}$ in the exon 2 of the OPRK1 (Gerra et al., 2007), and T921C in the exon 1 of the OPRD1 (Franke et al., 1999) were amplified using primers provided in Table 1. PCR amplifications were performed in $20 \mu \mathrm{L}$ PCR reaction system consisting of $20 \mathrm{mM}$ Tris- $\mathrm{HCl} \mathrm{pH}$ 8.0, $50 \mathrm{mM}$ EDTA, $0.2 \mathrm{mM}$ dNTPs, $1.5 \mathrm{mM} \mathrm{MgCl} 2,0.5$ $\mu \mathrm{mol}$ each primer (forward and reverse) and 2.5 units of Taq polymerase (Kumar, Chakraborty, \& Das, 2012). The PCR reactions were programmed as follows. For OPRD, we used an initial denaturation at $95^{\circ} \mathrm{C}$ for $3 \mathrm{~min}$, 40 cycles at $95^{\circ} \mathrm{C}$ for $50 \mathrm{~s}, 66^{\circ} \mathrm{C}$ for $90 \mathrm{~s}$ and $72^{\circ} \mathrm{C}$ for 90 $\mathrm{s}$. The reaction was terminated by an elongation period at $72^{\circ} \mathrm{C}$ for $6 \mathrm{~min}$. For OPRM, we used an initial denaturation at $95^{\circ} \mathrm{C}$ for $5 \mathrm{~min}$, followed by 45 cycles at $95^{\circ} \mathrm{C}$ for $10 \mathrm{~s}, 50^{\circ} \mathrm{C}$ for $150 \mathrm{~s}$ and $72^{\circ} \mathrm{C}$ for $15 \mathrm{~s}$ with a final elongation time at $72^{\circ} \mathrm{C}$ for $6 \mathrm{~min}$. The same annealing temperature was used for $\beta$-actin. For OPRK, we used the same program as OPRM with 43 cycles and $55^{\circ} \mathrm{C}$ annealing temperature. PCR products were separated by electrophoresis in $1.5 \%$ agarose gel at $100 \mathrm{~V}$. PCR products size $(301,300$, and 294 bp for OPRM, OPRK, and OPRD, respectively) confirmation was performed using a $1 \%$ agarose gel stained by ethidium-bromide and visualized by UV light. Automated DNA sequencing was performed using the primer described above and the Apr 
Table 1. List of primers in the study

\begin{tabular}{cccc}
\hline Gene & SNP & Forward Primers & Reverse Primers \\
\hline OPRM & A118G & 5'-GCTTGGAACCCGAAAAGTC-3' & 5'-GTAGAGGGCCATGATCGTGAT-3 \\
OPRK & G36T & 5'-CGTGCGCTGAGAGGCGGGGG-3 & 5'-GCCGTGATGATGACCGGGATG-3 \\
OPRD & T921C & 5'-GGTGTGCATGCTCCAGTTCC-3 & 5'-CGCGCCGGTCGATGTCCACC-3 \\
\hline
\end{tabular}

NEUR SCIENCE

plied Biosystems TaqMan platform (Source Bioscience Sequencing, Cambridge, UK). Sequences were assembled by using Chromas.

\subsection{Statistical analysis}

We used SPSS 20 (SPSS Inc., Chicago, IL, USA) to analyze the obtained data. The genotype frequencies of OPRM, OPRD, and OPRK markers were compared between cases and controls through the single-locus casecontrol test function in PowerMarker.

\section{Results}

After separation of PCR products on 1\% agarose gel, the bands were visualized by UV light. As shown in Figures 1, 2, and 3, the PCR products size were 301, 300, and 294 bp for OPRM, OPRK, and OPRD, respectively. The results of automated DNA sequencing were assembled by using Chromas (Table 2). Analysis of sequencing of OPRM showed no difference between the case and control group and the all of cases expressed the A nucleotide. Similar to OPRM, there was no variation in OPRK and OPRD sequencings. Finally, our results showed no association between heroin dependence and A118G, G36 T, and T921 C SNPs in the OPRM, OPRK, and OPRD, respectively. A possible explanation for these results may lie in the diversity of allele frequency across and within populations.

\section{Discussion}

Addiction to drugs is influenced by physiological, psychological, pharmacological, genetic and environmental factors. Furthermore, genetic parameters play an important role in the pathogenesis of opioid addiction; heritability nature of opioid abuse and or addiction ranges from $43 \%$ to $60 \%$ (Goldman, Oroszi, \& Ducci, 2005; Li $\&$ Burmeister, 2009). Numerous lines of evidence has demonstrated a connection between opioid receptor variability and substance addiction in humans (Kowarik et al., 2012; Soto \& Raingo, 2012). In this regard, Mayer et al. reported an association between DOR polymorphism and heroin dependence in men (Mayer et al., 1997). They showed that allele $\mathrm{C}$ was more frequent in German Caucasian heroin addicts than in controls. Studies on experimental animals have shown that genetic polymorphisms in KORs play a role in having tendency toward voluntary alcohol-drinking behavior (Saito et al., 2003; Vadasz, Saito, Gyetvai, \& Mikics, 2000). In addition, preliminary studies in humans revealed that 36 G>T SNP on the KOR gene (hOPRK1) displays a strong association with A variety of addictive diseases (Yuferov et al., 2004). According to another study, heroin dependency is shown to be correlated with a high frequency of allele $36 \mathrm{G}>\mathrm{T}$ SNP in the exon 2 of the human KOR gene (hOPRK1), proposing that the $\mathrm{T}$ allele might predispose people to addictive behavior or to personality traits at risk for substance abuse (Gerra et al., 2007).

Table 2. Sequencing of the genes

\begin{tabular}{|c|c|}
\hline Gene & Sequencing \\
\hline OPRM & $\begin{array}{l}\text { GCTTGGAACCCGAAAAGTCTCGGTGCTCCTGGCTACCTCGCACAGCGGTGCCCGCCCGGCCGTCAGTACCATGGACAGCAGCGCT- } \\
\text { GCCCCCACGAACGCCAGCAATTGCACTGATGCCTTGGCGTACTCAAGTTGCTCCCCAGCACCCAGCCCCGGTTCCTGGGTCAACTT- } \\
\text { GTCCCACTTAGATGGCAACCTGTCCGACCCATGCGGTCCGAACCGCACCGACCTGGGCGGGAGAGACAGCCTGTGCCCTCCGACCG- } \\
\text { GCAGTCCCTCCATGATCACGGCCATCACGATCATGGCCCTCTAC }\end{array}$ \\
\hline OPRK & $\begin{array}{l}\text { AGTGGGAGACGTGCGCTGAGAGGCGGGGGCTGCGCTCGGCGGAACAGCAGCCCTCGGGCGGAGAGCGGGGCCGGGGTCCGAGA- } \\
\text { GCAGGTGATGCCAAGAGCTGAGCGGGACTCGTGAGCGCGCGGTTCAGCACCTACCAGGGCGTCCCGTAAAAAACCTCGCCTTCGCCT- } \\
\text { GTCTCTGGGAACCATAGGTAAGCTTTGGGCTTTCGAGGTGCAGTTCTAGGTAGAGCTCCGTGCTGGGAGGTGGGAAGGGGGCTT- } \\
\text { GACCCTGGGGACTCAGGCAGTCTGGG }\end{array}$ \\
\hline OPRD & $\begin{array}{l}\text { GGTGTGCATGCTCCAGTTCCCCAGCCCCAGCTGGTACTGGGACACGGTGACCAAGATCTGCGTGTTCCTCTTCGCCTTCGTGGTGCCCATCCT- } \\
\text { CATCATCACCGTGTGCTATGGCCTCATGCTGCTGCGCCTGCGCAGTGTGCGCCTGCTGTCGGGCTCCAAGGAGAAGGACCGCAGCCTGCG- } \\
\text { GCGCATCACGCGCATGGTGCTGGTGGTTGTGGGCGCCTTCGTGGTGTGTTGGGCGCCCATCCACATCTTCGTCATCGTCTGGACGCTGGTG- } \\
\text { GACATCGACCGGCGCG }\end{array}$ \\
\hline
\end{tabular}




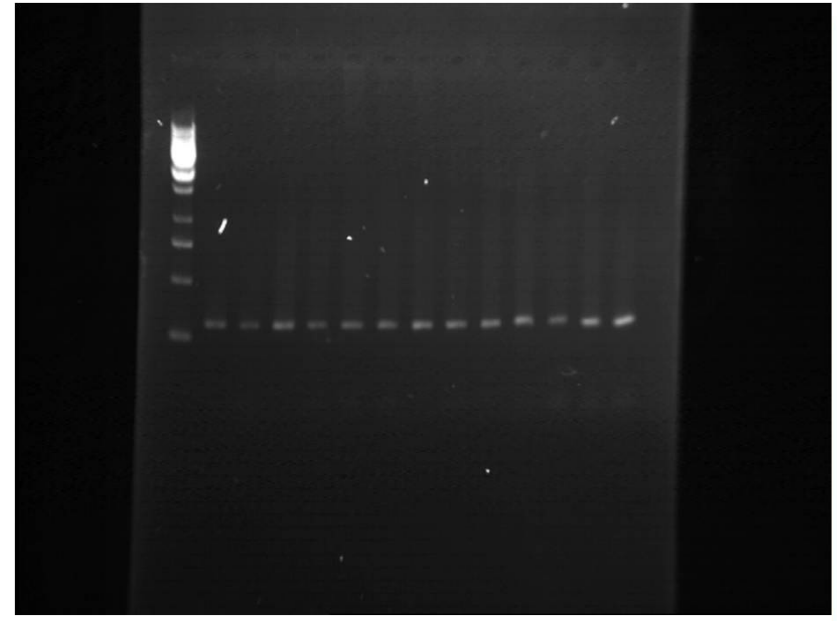

GeneRuler $^{\text {TM }} 1$ kb DNA Ladder

0'GeneRuler ${ }^{\text {TM }} 1$ kb DNA Ladder, ready-to-use

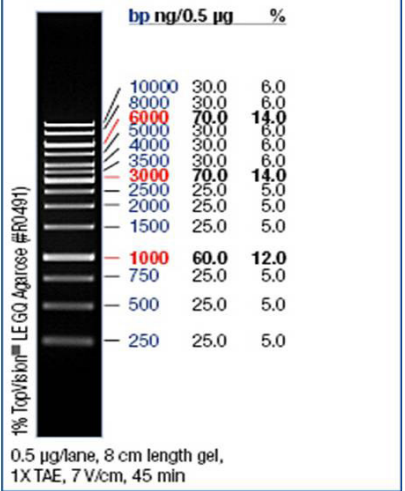

Figure 1. OPRM gene expression on agarose 1\% gel (301 bp)

NEUR:SCIENCE
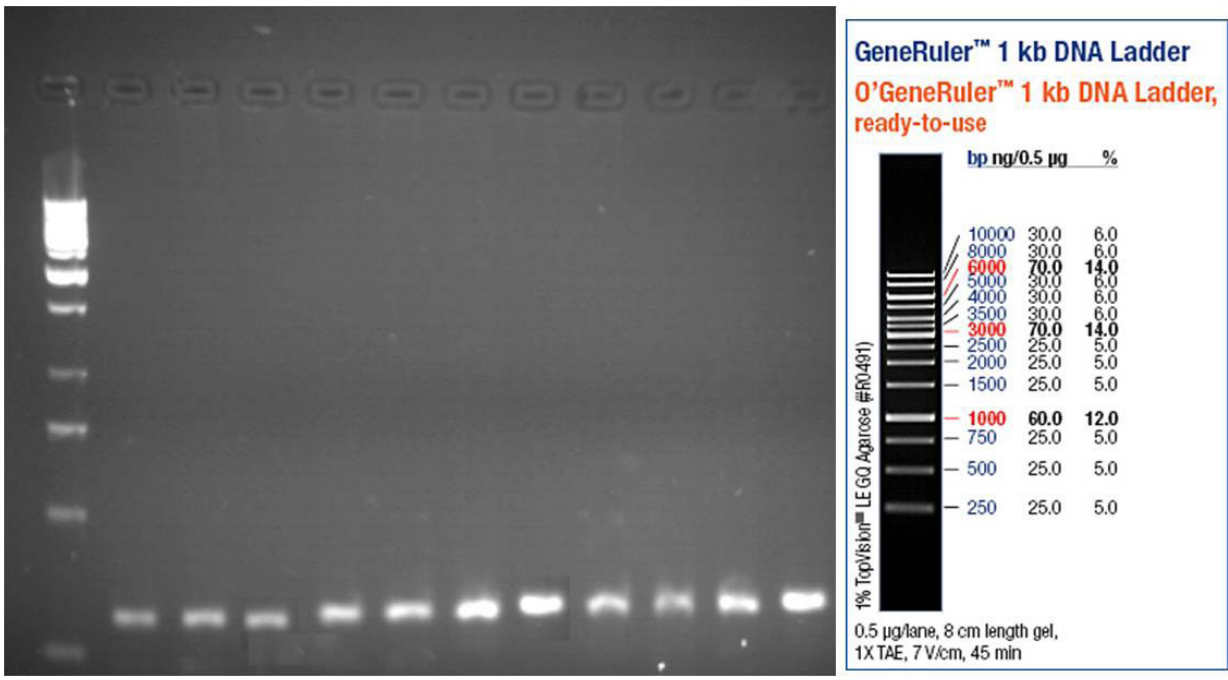

Figure 2. OPRK gene expression on agarose 1\% gel (300 bp)

NEUR SCIENCE
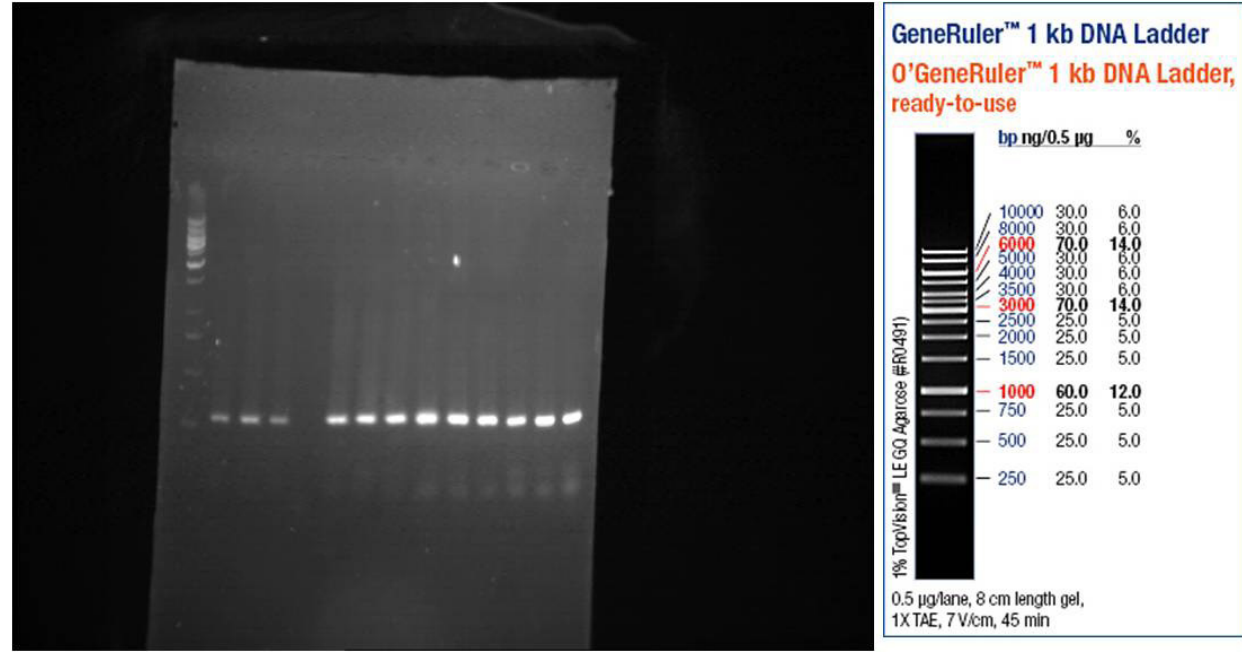

Figure 3. OPRD gene expression on agarose 1\% gel (294 bp) 
The present findings indicate no association between opioid dependency and novel polymorphisms A118G, $36 \mathrm{G}>\mathrm{T}$, 921C SNP in MOR, KOR, DOR genes, respectively in contrast to the previously mentioned study. There are number of studies that consistent with our results. In this context, Bond and colleagues found no significant differences in A118G allele frequency between opioid dependent and non-dependent subjects with all ethnic groups combined (Bond et al., 1998). In another study on a European population, no significant association was shown between this SNP and opioid addiction (Beer et al., 2013). However in subgroup analysis by ethnicity, the A118G minor allele $(G)$ frequency was significantly higher in non-opioid dependent Hispanic subjects (Bond et al., 1998). A study by Bart et al. also corroborated this association on a Swedish population of opiate-dependent and control subjects, demonstrating higher frequencies of the minor allele in opiate-dependent users (Bart et al., 2004).

Study on MOR and KOR genes in Taiwanese population revealed no significant differences in genotype frequency or allele on subjects with alcohol dependency and controls (Loh, Fann, Chang, Chang, \& Cheng, 2004). In addition, Franke et al. findings do not support the hypothesis that the $\mathrm{C}$ allele elevates the risk of substance abuse, neither for alcohol dependence nor for heroin dependence (Franke et al., 1999). In a European American population study by Zhang et al., no significant association was shown between this SNP with alcohol, cocaine, and opioid dependence (Zhang, Kranzler, Yang, Luo, \& Gelernter, 2007). In contrast to these reports, Mayer et al. showed that the abundance a silent $\mathrm{T}$ to $\mathrm{C}$ substitution in site 921 of the $\delta$-opioid receptor gene was significantly higher in heroin addicts than in control population (Mayer et al., 1997). The stressful events, personality disorders and negative emotional relationships, such as parent-child relationships, are considered predictors of addictive behaviors (Conner, Hellemann, Ritchie, \& Noble, 2010). This is a good evidence for complex diseases where the genetic etiology is indicative of multifactorial syndrome. The genetic effects on any behavioral outcome are influenced by exposure of individual to a certain environment. Thus, when interpreting the findings, interactions between environmental and genetic factors should be considered, for example, the tendency of individuals to purposefully adapt to specific environments.

Our findings suggest that opioid receptor gene polymorphisms do not have a significant influence on the progress of heroin dependence among the Iranian population. Further studies are necessary to examine vari- ables of opioid receptors genotype and its relation with individuals' characteristics at risk to addictive behavior.

\section{Acknowledgements}

This study was financially supported by Iran University of Medical Sciences.

\section{Conflict of Interest}

None of the authors have a financial interest to report.

\section{References}

Bart, G., Heilig, M., LaForge, K., Pollak, L., Leal, S., Ott, J., et al. (2004). Substantial attributable risk related to a functional mu-opioid receptor gene polymorphism in association with heroin addiction in central Sweden. Molecular Psychiatry, 9(6), 547-49. doi: 10.1038/sj.mp.4001504

Beer, B., Erb, R., Pavlic, M., Ulmer, H., Giacomuzzi, S., Riemer Y., \& Oberacher, H. (2013). Association ofpolymorphisms in pharmacogenetic candidate genes (OPRD1, GAL, ABCB1, OPRM1) with opioid dependence in European population: A case-control study. PLoS ONE, 8(9), e75359. doi: 10.1371/ journal.pone.0075359

Bond, C., LaForge, K. S., Tian, M., Melia, D., Zhang, S., Borg, L., et al. (1998). Single-nucleotide polymorphism in the human mu opioid receptor gene alters $\beta$-endorphin binding and activity: Possible implications for opiate addiction. Proceedings of the National Academy of Sciences, 95(16), 9608-13. doi: 10.1073/ pnas.95.16.9608

Conner, B. T., Hellemann, G. S., Ritchie, T. L., \& Noble, E. P. (2010). Genetic, personality, and environmental predictors of drug use in adolescents. Journal of Substance Abuse Treatment, 38(2), 178-190. doi: 10.1016/j.jsat.2009.07.004

Crist, R., Doyle, G., Kampman, K., \& Berrettini, W. (2016). A delta-opioid receptor genetic variant is associated with abstinence prior to and during cocaine dependence treatment. Drug and Alcohol Dependence, 166, 268-71. doi: 10.1016/j. drugalcdep.2016.07.008

Degenhardt, L., Whiteford, H. A., Ferrari, A. J., Baxter, A. J., Charlson, F. J., Hall, W. D., et al. (2013). Global burden of disease attributable to illicit drug use and dependence: findings from the Global Burden of Disease Study 2010. The Lancet, 382(9904), 1564-74. doi: 10.1016/s0140-6736(13)61530-5

Franke, P., Nöthen, M. M., Wang, T., Neidt, H., Knapp, M., Li chtermann, D., et al. (1999). Human $\delta$-opioid receptor gene and susceptibility to heroin and alcohol dependence. American Journal of Medical Genetics, 88(5), 462-4. doi: 10.1002/(sici)10968628(19991015)88:5<462::aid-ajmg4>3.0.co;2-s

Gelernter, J., \& Kranzler, H. R. (2000). Variant detection at the $\delta$ opioid receptor (OPRD1) locus and population genetics of a novel variant affecting protein sequence. Human Genetics, 107(1), 86-88. doi: 10.1007/s004390050016 
Gerra, G., Leonardi, C., Cortese, E., D'Amore, A., Lucchini, A., Strepparola, G., et al. (2007). Human kappa opioid receptor gene (OPRK1) polymorphism is associated with opiate addiction. American Journal of Medical Genetics Part B: Neuropsychiatric Genetics, 144B(6), 771-5. doi: 10.1002/ajmg.b.30510

Goldman, D., Oroszi, G., \& Ducci, F. (2005). The genetics of addictions: uncovering the genes. Nature Reviews Genetics, 6(7), 521-32. doi: $10.1038 / \operatorname{nrg} 1635$

Grösch, S., Niederberger, E., Lötsch, J., Skarke, C., \& Geisslinger, G. (2001). A rapid screening method for a Single Nucleotide Polymorphism (SNP) in the human MOR gene. British Journal of Clinical Pharmacology, 52(6), 711-714. doi: 10.1046/j.03065251.2001.01504.x

Koch, T., Kroslak, T., Averbeck, M., Mayer, P., Schröder, H., Raulf, E., et al. (2000). Allelic variation S268P of the human $\mu$-opioid receptor affects both desensitization and $\mathrm{G}$ protein coupling. Molecular Pharmacology, 58(2), 328-334. doi: 10.1124/ mol.58.2.328

Kowarik, M. C., Einhäuser, J., Jochim, B., Büttner, A., Tölle, T. R., Riemenschneider, M., et al. (2012). Impact of the COMT Val 108/158 Met polymorphism on the mu-opioid receptor system in the human brain: Mu-opioid receptor, met-enkephalin and beta-endorphin expression. Neuroscience Letters, 506(2), 214-219. doi: 10.1016/j.neulet.2011.11.008

Kreek, M. J., Bart, G., Lilly, C., Laforge, K. S., \& Nielsen, D. A. (2005). Pharmacogenetics and human molecular genetics of opiate and cocaine addictions and their treatments. Pharmacological Reviews, 57(1), 1-26. doi: 10.1124/pr.57.1.1

Kumar, D., Chakraborty, J., \& Das, S. (2012). Epistatic effects between variants of kappa-opioid receptor gene and A118G of mu-opioid receptor gene increase susceptibility to addiction in Indian population. Progress in Neuro-Psychopharmacology and Biological Psychiatry, 36(2), 225-30. doi: 10.1016/j. pnpbp.2011.10.018

Li, M. D., \& Burmeister, M. (2009). New insights into the genetics of addiction. Nature Reviews Genetics, 10(4), 225-31. doi $10.1038 / \operatorname{nrg} 2536$

Loh, E. W., Fann, C. S., Chang, Y. T., Chang, C. J., \& Cheng, A. T. (2004). Endogenous opioid receptor genes and alcohol dependence among Taiwanese Han. Alcoholism: Clinical and Experimental Research, 28(1), 15-19. doi: 10.1097/01. alc.0000106303.41755.b8

Majdzadeh, R., Feiz-Zadeh, A., Rajabpour, Z., Motevalian, A., Hosseini, M., Abdollahi, M., et al. (2009). Opium consumption and the risk of traffic injuries in regular users: A case-crossover study in an emergency department. Traffic Injury Prevention, 10(4), 325-29. doi: 10.1080/15389580902995380

Mayer, P., Rochlitz, H., Rauch, E., Rommelspacher, H., Hasse, H. E., Schmidt, S., et al. (1997). Association between a delta opioid receptor gene polymorphism and heroin dependence in man. NeuroReport, 8(11), 2547-50. doi: 10.1097/00001756199707280-00025

Oslin, D. W., Berrettini, W., Kranzler, H. R., Pettinati, H., Gelernter, J., Volpicelli, J. R., et al. (2003). A functional polymorphism of the $\mu$-opioid receptor gene is associated with naltrexone response in alcohol-dependent patients. Neuropsychopharmacology, 28(8), 1546-1552. doi:10.1038/sj.npp.1300219

Saito, M., Ehringer, M. A., Toth, R., Oros, M., Szakall, I., Sikela, J. M., et al. (2003). Variants of k-opioid receptor gene and mRNA in alcohol-preferring and alcohol-avoiding mice. Alcohol, 29(1), 39-49. doi: 10.1016/s0741-8329(02)00322-1

Shadnia, S., Soltaninejad, K., Heydari, K., Sasanian, G., \& Abdollahi, M. (2008). Tramadol intoxication: A review of 114 cases. Human \& experimental toxicology, 27(3), 201-5.

Sharafshah, A., Fazel, H., Albonaim, A., Omarmeli, V., Rezaei, S., Mirzajani, E., et al. (2017). Association of OPRD1 gene variants with opioid dependence in addicted male individuals undergoing methadone treatment in the north of Iran. Journal of Psychoactive Drugs, 49(3), 242-51. doi: 10.1080/02791072.2017.1290303

Soto, E. J. L., \& Raingo, J. (2012). A118G mu opioid receptor polymorphism increases inhibitory effects on $\mathrm{CaV} 2.2$ channels. Neuroscience Letters, 523(2), 190-4. doi: 10.1016/j.neulet.2012.06.074

Stein, C. (2016). Opioid receptors. Annual Review of Medicine, 67(1), 433-51. doi: 10.1146/annurev-med-062613-093100

Vadasz, C., Saito, M., Gyetvai, B., \& Mikics, E. (2000). Scanning of five chromosomes for alcohol consumption loci. Alcohol, 22(1), 25-34. doi: 10.1016/s0741-8329(00)00098-7

Wang, D., Quillan, J. M., Winans, K., Lucas, J. L., \& Sadée, W. (2001). Single nucleotide polymorphisms in the human $\mu$ opioid receptor gene alter basal $G$ protein coupling and calmodulin binding. Journal of Biological Chemistry, 276(37), 34624-30 doi: $10.1074 /$ jbc.m104083200

Yuferov, V., Fussell, D., LaForge, K. S., Nielsen, D. A., Gordon, D., Ho, A., et al. (2004). Redefinition of the human kappa opioid receptor gene (OPRK1) structure and association of haplotypes with opiate addiction. Pharmacogenetics, 14(12), 793-804. doi: 10.1097/00008571-200412000-00002

Yuferov, V., Levran, O., Proudnikov, D., Nielsen, D. A., \& Kreek M. J. (2010). Search for genetic markers and functional variants involved in the development of opiate and cocaine addiction and treatment. Annals of the New York Academy of Sciences, 1187(1), 184-207. doi: 10.1111/j.1749-6632.2009.05275.x

Zhang, H., Kranzler, H., Yang, B., Luo, X., \& Gelernter, J. (2007). The OPRD1 and OPRK1 loci in alcohol or drug dependence: OPRD1 variation modulates substance dependence risk. Molecular Psychiatry, 13(5), 531-43. doi: 10.1038/sj.mp.4002035 